\title{
Initial challenges in the career of ophthalmologists
}

\section{Óbices iniciais na carreira do oftalmologista}

Rodrigo Pessoa Cavalcanti Lira ${ }^{1}$, Fernando Rodrigo Pereira Chaves $^{1}$, Carlos Eduardo Leite Arieta ${ }^{1}$

\section{Dear Editor,}

The curriculum of most ophthalmology courses does not include or has not emphasized the fundaments of management, marketing, economics, and accounting in private practice. Consequently, the young ophthalmologists enter the labor market without a proper understanding of these important aspects of a career.

The inexperience in dealing with routine tasks of a business, such as taxes, cash flow, and bank loans, are factors that can lead to the closure of the medical office in its first years of life ${ }^{(1)}$. The aim of this study is to describe the main challenges faced by young ophthalmologists in the first decade of their career.

We conducted a descriptive study with physicians from Brazil, who attended an ophthalmology congress. Inclusion criteria were as follows: being medical ophthalmologist under 40 years of age, and having completed more than 5 and less than 10 years of specialization in ophthalmology. The procedures followed were in accordance with the ethical standards of the responsible committee on human experimentation and with the Helsinki Declaration

From the database of the congress, participants who met the inclusion criteria were randomly invited to answer two questionnaires.

In the first questionnaire, by e-mail, we collected data on gender, age, time of completion of specialization, and the answer to the following question: What were the three major challenges in your personal experience during the exercise of ophthalmology? Challenges were defined as the personal choices made at the beginning of the career that contributed negatively to professional success. After accounting for the initial results, the 10 most frequently mentioned answers were listed.

In the second questionnaire, the same volunteers were once again interviewed by e-mail and asked to choose, among this 10-item list, the three major challenges in their personal experience. The order of presentation of the options was randomly different for each volunteer to provide equal exposure of each item.

Forty-eight ophthalmologists were interviewed, with a mean age of 37 years (SD: 2 years, range: 33-40 years) and mean time of com- pletion of the specialization course in ophthalmology of 8 years (SD: 1 year, range: 5-10 years). Twenty-four (50\%) were male. All agreed to participate. Table 1 details the frequency of answers ( 144 citations=3 per respondent).

The lack of administrative and financial knowledge was the most common difficulty faced by young ophthalmologists in the first decade of their careers. This fact is unfortunate, considering the various sources of supplementary education that can meet much of this

Table 1. Initial challenges in the career in ophthalmology

\begin{tabular}{lcccc}
\hline Item & $\begin{array}{c}\text { Frequency } \\
\text { N (\%) }\end{array}$ & $\begin{array}{c}\text { Male } \\
\text { N (\%) }\end{array}$ & $\begin{array}{c}\text { Female } \\
\text { N (\%) }\end{array}$ & P \\
\hline $\begin{array}{l}\text { Lack of administrative and } \\
\text { financial knowledge }\end{array}$ & $42(29.2)$ & $18(25.0)$ & $24(33.3)$ & $0.27^{*}$ \\
$\begin{array}{l}\text { Delay in opening own business } \\
\text { Working in many places }\end{array}$ & $28(19.4)$ & $11(15.2)$ & $17(23.6)$ & $0.21^{*}$ \\
simultaneously & $24(16.7)$ & $11(15.2)$ & $13(18.0)$ & $0.65^{*}$ \\
$\begin{array}{l}\text { Association with persons of } \\
\text { dubious reputation }\end{array}$ & $9(6.3)$ & $6(8.3)$ & $3(4.1)$ & $0.49^{\dagger}$ \\
$\begin{array}{l}\text { Having to submit to unethical } \\
\text { working conditions }\end{array}$ & $9(6.3)$ & $4(5.5)$ & $5(6.9)$ & $0.99^{\dagger}$ \\
$\begin{array}{l}\text { Corporate group expansion } \\
\text { without set standards }\end{array}$ & $9(6.3)$ & $7(9.7)$ & $2(2.7)$ & $0.17^{\dagger}$ \\
$\begin{array}{l}\text { Exclusive dedication to a job } \\
\text { Lack of alternative career plan }\end{array}$ & $7(4.9)$ & $1(1.3)$ & $6(8.3)$ & $0.12^{\dagger}$ \\
Hastiness & $6(4.2)$ & $4(5.5)$ & $2(2.7)$ & $0.68^{\dagger}$ \\
Lack of humility & $6(4.2)$ & $6(8.3)$ & $0(0)$ & $0.03^{\dagger}$ \\
Total & $4(2.8)$ & $4(5.5)$ & $0(0)$ & $0.12^{\dagger}$ \\
\hline
\end{tabular}

${ }^{*}=$ Chi-square test; ${ }^{\dagger}=$ Fisher's exact test. 
demand for knowledge ${ }^{(2-4)}$. For example, in 2006, the International Council of Ophthalmology published the "Principles and Guidelines of a Curriculum for Education of the Ophthalmic Specialist"(5). It includes specific management issues such as cooperativism, civil society, marketing, contract negotiation, professional defense, career planning, retirement, consumer protection codes, employee recruitment, clinic management, auditing, quality strategies, taxation, applied financial mathematics, billing, health surveillance, legislation, among others ${ }^{(5)}$ Although the sample of this study was not designed to test gender differences (there was no statistically significant difference), some interesting findings were observed. For example, the delay in opening own business and the exclusive dedication to a job, were most cited by women. Conversely, the lack of humility, the hastiness, and the corporate group expansion without set standards, were most cited by men.

Studies to evaluate professional practice of young ophthalmologists are scarce. The authors are unaware of previous manuscript describing the major challenges of ophthalmologists in the first decade of their career and we could find no reference to it in a computerized search at PubMed. Although these results should not be generalized, they may help not only those at the beginning of their career but also every ophthalmologist who wants to reflect on what to prioritize in their professional practice.

\section{REFERENCES}

1. Serviço Brasileiro de Apoio a Micro e Pequena Empresa. 10 anos de monitoramento da sobrevivência e mortalidade de Empresas [Internet]. São Paulo: SEBRAE-SP; 2008. [citado 2012 Dec 21]. Disponível em: http://www.sebraesp.com.br/arquivos_site/ biblioteca/EstudosPesquisas/mortalidade/livro_10_anos_mortalidade.pdf\%20\%20

2. Chiarantano S, Regonha E, Scarpi MJ. O controle financeiro e seus benefícios na estruturação de clínica oftalmológica. Rev Adm Saúde [Internet] 2006[citado 2010 Apr 23];8(3):33-9. Disponível em: http://www.cqh.org.br/files/RAS30_o\%20controle.pdf

3. Olson RJ. Ten-year experience in managing a capitates ophthalmology carve-out by an academic eye center. J Ambul Care Manage. 1997:20(1):1-7.

4. Solomon MD, Lee PP, Mangione CM, Kapur K, Adam JL, Wickstrom SL, et al. Characteristics of eye care practices with managed care contracts. Am J Manag Care. 2002; 8(12):1057-67

5. International Council of Ophthalmology. Principles and guidelines of a curriculum for education of the ophthalmic specialist. Klin Monbl Augenheilkd. 2006;223(Suppl 4):S3-48.
Submitted for publication: May 23, 2013

Accepted for publication: May 29, 2013

${ }^{1}$ Universidade Estadual de Campinas.
Funding: No specific financial support was available for this study.

Disclosure of potential conflicts of interest: R.P.C.Lira, None; F.R.P.Chaves, None; C.E.L.Arieta, None.

Correspondence address: Rodrigo Pessoa Cavalcanti Lira. Rua Irma Maria David, 200 - Apto. 1302 - 52061-070 - Recife (PE) - E-mail: rodrigopclira@hotmail.com 